\title{
Use of ibuprofen in the context of the SARS-CoV-2 pandemic
}

\author{
Utilizarea ibuprofenului în contextul pandemiei SARS-CoV-2
}

Octavia Sabin, Anca Dana Buzoianu
Disciplina Farmacologie, Toxicologie și Farmacologie Clinică,
Universitatea de Medicină și Farmacie „,Iuliu Hațieganu“, Cluj-Napoca, România

\begin{abstract}
A few months after the onset of the 2019 coronavirus disease pandemic (COVID-19), it has been suggested that the use of certain nonsteroidal anti-inflammatory drugs may increase the severity and mortality of the disease, therefore it should be avoided in those who become ill. The hypothesis was based on previous preclinical and clinical studies that analyzed the role of cyclooxygenase in inflammatory processes in viral infections. Based on the existing data analyzed, there is no evidence of a worsening of the disease in patients previously treated with ibuprofen.
\end{abstract}

Keywords: ibuprofen, COVID-19, SARS-CoV-2

\begin{tabular}{|l} 
REZUMAT \\
La câteva luni de la declanșarea pandemiei bolii coronavirus 2019 (COVID-19), s-a sugerat că utilizarea anu- \\
mitor antiinflamatoare nesteroidiene poate crește severitatea și mortalitatea bolii, ca urmare ar trebui evitate la \\
cei care se îmbolnăvesc. Ipoteza inițială s-a bazat pe studii preclinice și clinice anterioare care au analizat rolul \\
ciclooxigenazei în procesele inflamatorii din infecții virale. Pe baza datelor existente analizate, nu există dovezi \\
care să demonstreze o agravare a bolii la pacienții tratați anterior cu ibuprofen.
\end{tabular}

\section{INTRODUCERE}

Începând cu ianuarie 2020, lumea întreagă este afectată de cea mai severă pandemie din secolul XXI, cea a infecției cu SARS-CoV-2. Având în vedere numărul mare de îmbolnăviri și lipsa unor mijloace foarte eficiente și specifice pentru combaterea bolii, descoperirea factorilor care ar putea influența evoluția bolii este esențială. În acest context, asocierea posibilă a utilizării de antiinflamatoare nesteroidiene (AINS) și un raport de risc crescut al formelor severe de boală au fost luate în discuție.

\section{DE UNDE A PORNIT?}

În luna martie, în plină criză pandemică COVID-19 în Europa de vest, au apărut informații privind un posibil risc asociat administrării de ibuprofen în cazul infecției SARS-CoV-2. Informația care a declanșat o avalanșă de reacții a pornit de la ministrul francez al Sănătătii, Oliver Veran, care a scris pe Twitter că ,luarea de medicamente antiinflamatorii (ibuprofen, cortizon...) poate fi un factor agravant pentru infecție. Dacă aveți febră luați paracetamol“" (1). Această afirmație a fost făcută în urma unor raportări de posibile reacții adverse în sistemul de farmacovigilență, generate dintr-o secție de boli infecțioase din sud-vestul Franței, unde medicii au observat câteva cazuri grave de pacienți tineri, fără antecedente medicale serioase, care s-au tratat cu ibuprofen de la primele simptome şi, ulterior, au dezvoltat forme severe de boală (1). De menționat că medicii francezi erau familiarizați cu recomandarea ANSM din 2019 privind utilizarea paracetamolului de primă intenție în 
febră din cauza suspiciunii de asociere a unor AINS (ibuprofen și ketoprofen) cu cazuri de infecții bacteriene severe în context de infectii virale $(2,3)$.

De la aceste afirmații, internetul s-a împărțit în două, cu argumente de o parte și alta, creând o adevărată isterie mediatică. Experții au fost de acord să fie folosit paracetamolul de primă intenție în tratamentul simptomatic al febrei. Au fost emise rapid comunicate ale EMA (4) şi FDA (5) care au recomandat acest lucru, subliniind că, în acel moment, nu existau suficiente dovezi care să justifice contraindicarea ibuprofenului. OMS a comunicat inițial că pacienții nu ar trebui să utilizeze ibuprofen, revenind ulterior cu precizări de clarificare a comunicatului (6). Modul de comunicare a acestor recomandări, corect din punct de vedere științific, dar neclar pentru publicul larg, preluate trunchiat de unele publicații, a dus la o perpetuare a nesiguranței în rândul consumatorilor. Problema a devenit stringentă pentru pacienții care erau deja tratați cronic cu ibuprofen pentru alte indicații, nu ca antipiretic. S-a pus problema dacă este plauzibil ca AINS să adauge un risc în plus de agravare a bolii sau de deces în infectía cu SARS-CoV-2, având în vedere riscul crescut de evenimente cardiovasculare al acestora (7). EMA a recomandat precauție și evitarea unor decizii radicale, cum ar fi întreruperea tratamentului până când nu vor fi suficiente date epidemiologice care să demonstreze clar această asociere (4).

$\mathrm{Nu}$ este prima oară când siguranța AINS este pusă la îndoială în epidemii virale. Un exemplu devenit deja clasic în manualele de farmacologie este cazul pandemiei de gripă spaniolă din 1918. Se pare că o parte dintre pacienții tineri care au murit prezentau la necropsie un aspect de edem pulmonar hemoragic, asociat hiperventilației și încărcării pulmonare prin supradozarea aspirinei. Dozele mari de aspirină, de la 8 până la 31,2 g (!), folosite în acele vremuri, au dus la toxicitate pulmonară acută și creșterea riscului de infecții bacteriene, prin afectarea clearance-ului muco-ciliar (8).

\section{CE ȘTIM DESPRE IBUPROFEN?}

Ibuprofenul este un AINS și acționează prin inhibiția ciclooxigenazelor, enzime care catalizează transformarea acidului arahidonic în prostaglandine, prostaciclină și tromboxan, iar prin acest mecanism reduc inflamaţia, febra și durerea. Sunt utilizate pe scară largă, unele dintre ele sunt disponibile în farmacii fără prescripție medicală (7).

Ipoteza de la care s-a pornit în studiile referitoare la ibuprofen în COVID-19 este că AINS ar putea fi asociate cu o evoluție nefavorabilă a pacienților cu boli respiratorii virale prin unul sau mai multe din următoarele mecanisme:

- Direct: prin blocarea COX, AINS pot înlătura efectul protector al prostaglandinelor, reducând răspunsul imun, prin reducerea recrutării polimorfonuclearelor (8), pot reduce vindecarea (3) sau prin afectarea directă a unor organe (rinichi, vase) (7)

- Indirect: ca factor de confuzie, de exemplu, pacienții care dezvoltă pleurezie au șanse mai mari să fie tratați cu AINS pentru durere sau prin faptul că AINS în automedicație pot masca o parte dintre simptomele bolii, favorizând astfel prezentarea tardivă la medic (9).

- Mecanism specific pentru SARS-CoV-2 şi ibuprofen: ACE2 este unul dintre receptorii recunoscuți de virusul SARS-CoV-2 la nivelul membranei celulare. $\mathrm{O}$ expresie crescută a ACE2, indusă de utilizarea unor medicamente, de exemplu inhibitorii de enzimă de conversie a angiotensinei (IECA), ar putea favoriza pătrunderea virusului în celule (10). Un studiu pe șoareci a arătat că ibuprofenul poate crește expresia ACE2 la nivel membranar (11). Putem utiliza o astfel de cascadă logică pentru a afirma că efectul nefavorabil este plauzibil. Dar pentru moment sunt doar speculații, iar multe alte necunoscute pot influența efectul final; nu știm dacă ibuprofenul influențează expresia ACE2 la om sau dacă supraexpresia ACE2 este cauza unei evoluții severe a bolii. Cunoaștem deja că IECA nu se asociază cu risc crescut de deces în COVID-19 (12)

Despre AINS și alte infecții virale, în afara COVID-19, un review sistematic asupra opt studii, publicat în august 2020, cuprinzând peste 44.000 de pacienți, nu a putut face o asociere clară între consumul de AINS și complicații infecțioase, nu s-a putut face metaanaliză din cauza heterogenității datelor și riscului crescut de părtinire, prin lipsa ajustării covariabilelor. A fost observată doar o tendință de scădere a mortalității și de creștere a complicațiilor pleuro-pulmonare, insuficientă însă pentru un verdict (13). Autorii subliniază necesitatea atât a unor studii epidemiologice, cât și studii fundamentale, pe posibilele mecanisme de actiune directe, pentru clarificarea acestor aspecte în legătură cu COVID-19.

Un studiu observaţional multicentric pe 1222 pacienți spitalizaţi în Marea Britanie cu forme severe de COVID-19, dintre care 4,4\% tratați anterior cu AINS, nu a evidențiat o asociere între consumul 
anterior de AINS și mortalitatea COVID-19 (14). Un alt studiu de cohortă, recent publicat, în septembrie 2020, a analizat registrul danez de sănătate, incluzând toți pacienții diagnosticați pozitiv cu infecție SARS-CoV-2 din februarie până în aprilie. S-au evaluat mortalitatea, spitalizările, internările în terapie intensivă, ventilația mecanică și insuficiența renală acută și pentru niciun criteriu nu s-a găsit un raport de risc crescut pentru utilizatorii de AINS pe bază de prescripție medicală. Autorii subliniază că pot să apară erori din cauza faptului că nu toți pacienții au luat medicamentele continuu sau exact imediat după prescriere. De asemenea, nu neglijează riscul de factor de confuzie prin indicație (15).

Ca urmare, probabilitatea ca ibuprofenul să modifice substanțial prognosticul pacienților cu COVID-19 este foarte redusă, potrivit rezultatelor publicate până la această dată. De aceea, nu este justificat să ne abținem să prescriem acest medicament la pacienții care au nevoie. Paracetamolul rămâne în continuare de primă intenție ca tratament antipiretic și analgezic ușor. Însă nu trebuie să trecem cu vederea riscurile dovedite ale utilizării cronice ale AINS, cele gastro-intestinale, cardiovasculare și renale, precum și contraindicația de prescriere în ultimul trimestru de sarcină. În primul rând, acestea trebuie luate în considerare de către medici atunci când hotărăsc să prescrie AINS pentru o perioadă mai lungă de timp.

În privința acestui subiect, au fost câteva erori de comunicare care au stârnit critici, de exemplu informația inițială dată de ministrul francez. Încadrarea la comun a AINS cu antiinflamatoarele steroidiene, care au mecanisme de acţiune diferite, atragerea atenției publicului larg asupra unei observații clinice părtinitoare, care nu făcea parte dintr-un studiu mai larg care se permită evitarea erorilor, au avut drept consecință catalogarea acestor informații ca fake news, ceea ce este nedrept pentru cei care au judecat iniţial că acest mecanism este plauzibil. În cercetare, nu se lucrează în modul acesta, ci se emite o ipoteză de lucru, care poate fi confirmată sau nu de studii, iar acest lucru ia timp. Acum, după mai bine de 6 luni de atunci, avem mai multe informații. Studiului clinic RECOVERY a demonstrat că glucocorticoizii scad mortalitatea la pacienții gravi care au nevoie de oxigen suplimentar sau de ventilație mecanică (16), iar studiile observaționale discutate mai sus au arătat că nu există dovezi solide pentru evitarea ibuprofenului în COVID-19.

\section{CONCLUZII}

Pandemia COVID-19 s-a manifestat și cu infodemie, o avalanşă de informații pe toate canalele de informare, pornind de la jurnale medicale printre cele mai serioase până la ziare pentru publicul larg sau rețele de socializare. Unele informații pornite ca ipoteze s-au dovedit în timp a fi justificate, altele a fost deja uitate. O comunicare științifică eficientă care să se adreseze publicului larg poate să crească încrederea în știință, asigurându-se o mai bună colaborare în combaterea bolilor. Ca urmare, OMS recunoaște dezinformarea ca un nou risc pentru sănătatea publică. Sunt multe incertitudini, iar publicul vrea răspunsuri clare, cât mai repede, dar din păcate acest lucru nu este posibil, nu după metode științifice. Avem nevoie de studii clinice, dar avem nevoie și de cercetare fundamentală care, ulterior, să pivoteze spre cercetarea clinică și avem nevoie acută de buni comunicatori, de jurnaliști de știință care să prezinte realitățile cercetării științifice într-un ambalaj ușor de digerat de către publicul larg.

Conflict of interest: none declared Financial support: none declared

\section{BIBLIOGRAFIE}

1. Day M. COVID-19: ibuprofen should not be used for managing symptoms, say doctors and scientists. BMJ. 2020;368.

2. Anti-inflammatoires non stéroïdiens (AINS) et complications infectieuses graves - Point d'Information actualisé le 20/05/2020 ANSM : Agence nationale de sécurité du médicament et des produits de santé. Accessed September 29, 2020. https://www.ansm.sante. $\mathrm{fr} / \mathrm{S}$-informer/Points-d-information-Points-d-information/Anti-inflammatoires-non-steroidiens-AINS-et-complications-infectieuses-gravesPoint-d-Information-actualise-le-20-05-2020.

3. Voiriot G, Philippot Q, Elabbadi A, Elbim C, Chalumeau M, Fartoukh M. Risks Related to the Use of Non-Steroidal Anti-Inflammatory Drugs in Community-Acquired Pneumonia in Adult and Pediatric Patients. J Clin Med. 2019;8(6):786.

4. EMA gives advice on the use of non-steroidal anti-inflammatories for COVID-19. European Medicines Agency. Published March 18, 2020.
Accessed September 29, 2020. https://www.ema.europa.eu/en/news/ ema-gives-advice-use-non-steroidal-anti-inflammatories-covid-19.

5. Research $\mathrm{C}$ for DE and. FDA advises patients on use of non-steroidal anti-inflammatory drugs (NSAIDs) for COVID-19. FDA. Published online March 19, 2020. Accessed September 29, 2020. https://www. fda.gov/drugs/drug-safety-and-availability/fda-advises-patients-usenon-steroidal-anti-inflammatory-drugs-nsaids-covid-19

6. AFP. Updated: WHO Now Doesn't Recommend Avoiding Ibuprofen For COVID-19 Symptoms. ScienceAlert. Accessed September 29, 2020. https://www.sciencealert.com/who-recommends-to-avoid-takingibuprofen-for-covid-19-symptoms.

7. Coxib and traditional NSAID Trialists' (CNT) Collaboration, Bhala N, Emberson J, et al. Vascular and upper gastrointestinal effects of non-steroidal anti-inflammatory drugs: meta-analyses of individual participant data from randomised trials. Lancet Lond Engl. 2013; 382(9894):769-779. 
8. Starko KM. Salicylates and Pandemic Influenza Mortality, 1918-1919 Pharmacology, Pathology, and Historic Evidence. Clin Infect Dis. 2009;49(9):1405-1410.

9. Capuano A, Scavone C, Racagni G, Scaglione F. NSAIDs in patients with viral infections, including COVID-19: Victims or perpetrators? Pharmacol Res. 2020;157:104849.

10. Smart L, Fawkes N, Goggin P, et al. A narrative review of the potential pharmacological influence and safety of ibuprofen on coronavirus disease 19 (COVID-19), ACE2, and the immune system: a dichotomy of expectation and reality. Inflammopharmacology. Published online August 14, 2020.

11. Qiao W, Wang C, Chen B, et al. Ibuprofen attenuates cardiac fibrosis in streptozotocin-induced diabetic rats. Cardiology. 2015; 131(2):97-106

12. Flacco ME, Martellucci CA, Bravi F, et al. Treatment with ACE inhibitors or ARBs and risk of severe/lethal COVID-19: a metaanalysis. Heart. 2020;106(19):1519-1524.
13. Vaja R, Chan JSK, Ferreira P, et al. The COVID-19 ibuprofen controversy: A systematic review of NSAIDs in adult acute lower respiratory tract infections. Br J Clin Pharmacol. 2020.

14. Bruce E, Barlow-Pay F, Short R, et al. Prior Routine Use of Non-Steroidal Anti-Inflammatory Drugs (NSAIDs) and Important Outcomes in Hospitalised Patients with COVID-19. J Clin Med. 2020;9(8):2586.

15. Lund LC, Kristensen KB, Reilev M, et al. Adverse outcomes and mortality in users of non-steroidal anti-inflammatory drugs who tested positive for SARS-CoV-2: A Danish nationwide cohort study. PLOS Med. 2020;17(9):e1003308.

16. The RECOVERY Collaborative Group Dexamethasone in Hospitalized Patients with COVID-19 - Preliminary Report. N Engl J Med. 2020. 